\title{
Engineering Site Characterisation Using 2-D and 3-D Electrical Resistivity Tomography
}

\author{
Elijah A. Ayolabi ${ }^{1}$, Ibok J. E. Enoh ${ }^{1} \&$ Adetayo F. Folorunso ${ }^{1,2}$ \\ ${ }^{1}$ Department of Geosciences, University of Lagos, Nigeria \\ ${ }^{2}$ College of Marine Geosciences, Ocean University of China, Qingdao, China \\ Correspondence: Elijah A. Ayolabi, Department of Geosciences, University of Lagos, Nigeria. Tel: \\ 234-803-720-6074. E-mail: eojelabi@yahoo.com; eayolabi@unilag.edu.ng
}

Received: January 29, 2012 Accepted: February 14, 2012 Online Published: October 9, 2012

doi:10.5539/esr.v2n1p133

URL: http://dx.doi.org/10.5539/esr.v2n1p133

\begin{abstract}
Land reclaimed from water bodies or its equivalent (swamp, flood zones and abandon river channel) usually contain certain mechanically unstable geological formations (e.g. peat and clay) which are inimical to the foundation of engineering structures. Concerted effort must therefore be ensured to determine depth to competent layer across the proposed site as against conventional geotechnical test which is a point test. Complementary non invasive geophysical methods must be carried out for any engineering construction so as to ensure stability of building construction and avoid the devastating effects of building collapse rampant of late. Thus, electrical resistivity tomography and induced polarisation methods, constrained by percussion drilling, were used for the present study. The results of the 2-D and 3-D DC resistivity tomography using 64 multi-electrode systems with gradient electrode configuration along five parallel profiles with smallest electrode separation of $4.0 \mathrm{~m}$ on a total length of $252 \mathrm{~m}$ was interpreted using Earth Imager Inversion software. The subsurface was characterised by Peat/Clay sandwich between upper and lower Clayey-sand/Sandy-clay and Sand. The presence of Peat and Clay were correlated to the cause of chronic differential settlements of some engineering structures within the area. The depths to the sand material were observed between 17-47 m. At shallow depths, the sand materials were underlain by mobile clay/peat materials, which correlates with the depth to competent layer (Sand) achieved by percussion drilling in the range of 20-24 $\mathrm{m}$. This lithological sequence in which the near surface sand deposits are underlain by clay/peat saturated with water, gives a sense of instability to the overlaying sandy layer. To buttress this finding, residential and other public buildings surveyed in the entire area are marked with various degrees of distress, ranging from multiple cracks, sinking of building, partial collapse to complete collapse. It should be noted that the depth to the sand layer achieved during the research varied along the respective profiles. Thus application of 2-D resistivity tomography has revealed both the lateral and vertical variation in depth to competent sand layer within the study area as opposed to point information from CPT or Percussion drilling. This provides a useful guide to the site engineers in designing appropriate foundation structure.
\end{abstract}

Keywords: site characterization, percussion drilling, 2-D resistivity tomography, induce polarisation, peat/clay, competent layer, Star Dust Residential Estate

\section{Introduction}

The pressure of providing basic housing infrastructure especially in congested ever-expanding cosmopolitan cities around the globe has led to the reclamation of land from lagoon, sea and other water bodies such as swamp, river, buried river channels, flood zones and similar places that have been left bare as a result of their inability to accommodate engineering structures. Places such as swamp belts, flood plains and buried river channel might have been filled up to the local datum through sedimentation of different organic matters and debris. The meandering streams of different drainage and river channels must have passed through different regions along its path depositing different materials at different regions within its locality at different times. These regions are naturally flooded due to the presence of impermeable soil layer - usually clay, resulting in sedimentation from moving water bodies and the presence of peat material (a product of densely compacted and partially decayed organic substance) may be inevitable. In an environment where sedimentation takes place, geological materials might have a high 
gradient in thickness over a short distance. Other factors such as subsidence and fault can further complicate the variation in thickness of geological materials (Akintorinwa \& Adesoji, 2009).

The utilization of this kind of land area in erecting engineering structures therefore necessitates adequate precaution due to its poor mechanical stability. Unfortunately, there have always been inadequate precautionary measures alongside the presence of mechanically unstable soil materials in most structures erected on such piece of land which has led to avoidable and devastating collapse of building structures, with its attending consequences - death. Furthermore, they also contribute to the chronic differential settlement of houses and distressed buildings.

In order to ensure a proper foundation system for buildings within this type of area, adequate information about the subsurface is necessary. The conventional geotechnical method involves the Dutch cone penetrometer test, Laboratory tests and Shell and Auger boring test. Although in-situ in nature, these tests are limited to a point and they are valid under certain assumptions (Ayolabi, Folorunso, Adeoti, Matthew, \& Atakpo, 2009; Akintorinwa \& Adesoji, 2009).

A geotechnical-geophysical survey is often the most cost-effective and rapid means of obtaining subsurface information, especially over large study areas (Sirles, 2006). Geotechnical geophysics can be used to select borehole locations and can provide reliable information about the nature and variability of the subsurface between existing boreholes. An isolated geologic structure such as a limestone pinnacle might not be detected by a routine drilling program. However, an effective geophysical survey could detect the presence of the pinnacle and map the height and lateral extent of the same.

Other advantages of geotechnical-geophysics survey are related to site accessibility, portability, non-invasiveness, and operator safety. Geophysical equipments can often be deployed beneath bridges and power lines, in heavily forested areas, at contaminated sites, in urban areas, on steeply dipping slopes, in marshy terrains, on pavements or rocks, and in other areas that might not be easily accessible to drill rigs or conduct a cone penetration test (CPT). Also, most surface-based or airborne geophysical tools are non-invasive and, unlike boring or trenching, leave little (if any) negative impact on environmentally sensitive areas, contaminated ground, or private property. In addition, geophysical surveys are generally considered less dangerous than drilling since there are fewer risks associated with utility encounters and operations. Besides, geophysical surveys can enable engineers to reduce the number of required boreholes (Sirles, 2006). Several geophysical methods commonly employed include seismic refraction, seismic reflection, cross-hole seismic tomography, GPR, electromagnetism, electrical resistivity, induced polarization, magnetic, self-potential and gravity (Anderson, 2006; Wightman, Jalinoos, Sirles, \& Hanna, 2004).

In recent years, attention has been shifted to complementary geophysical methods in addition to engineering soil tests to better characterise the subsurface to curtail the menace of rampant building collapse. Among the commonly employed geophysical methods to compliment geotechnical data are electrical resistivity, seismic refraction, GPR and VLF-EM (Roth, Nyquist, \& Guzas, 2000; Schoor, 2002; Elawadi, El-Qady, Nigm, Shaaban, \& Ushijima, 2006; Owusu-Nimo \& Boadu, 2010; Folorunso, Ayolabi, Ariyo, \& Oyebanji, 2012). These methods are deployed to obtain necessary information from the subsurface such as soil lithology, depth to bedrock, location and orientation of buried fractures, faults, abandoned river channels and detection of compressible soil layer (clay/peat) buried beneath the surface (Reynolds, 1997; Ayolabi et al., 2009; Ayolabi, Folorunso, \& Oloruntola, 2010).

The present work aimed at characterising the subsurface soil around the study site using DC electrical resistivity tomography vis-a-vis the geotechnical data (boring). We intended to determine the correlation between the drilled holes and inverted 2-D resistivity images. Depth to competent layer in subsequent building construction could be derived from inverted resistivity image if a good correlation is achieved.

\section{The Study Area}

The study area is the proposed site for Star Dust Residential Estate located in Gbagada area of Lagos, Nigeria (Figure 1). It appeared the area is a region of subsidence compare with the adjoining Lagos landmass and thus, it is an active water flooding zone (Ayolabi et al., 2010). The area is well vegetated with grasses, reeds and other plants that are peculiar to swamp or water lodged regions. The soil is water logged during dry season but the water drains in some part during hot weather leaving behind a highly fracture surface as depicted in Figure 2, while some other part are inaccessible being highly swampy. 


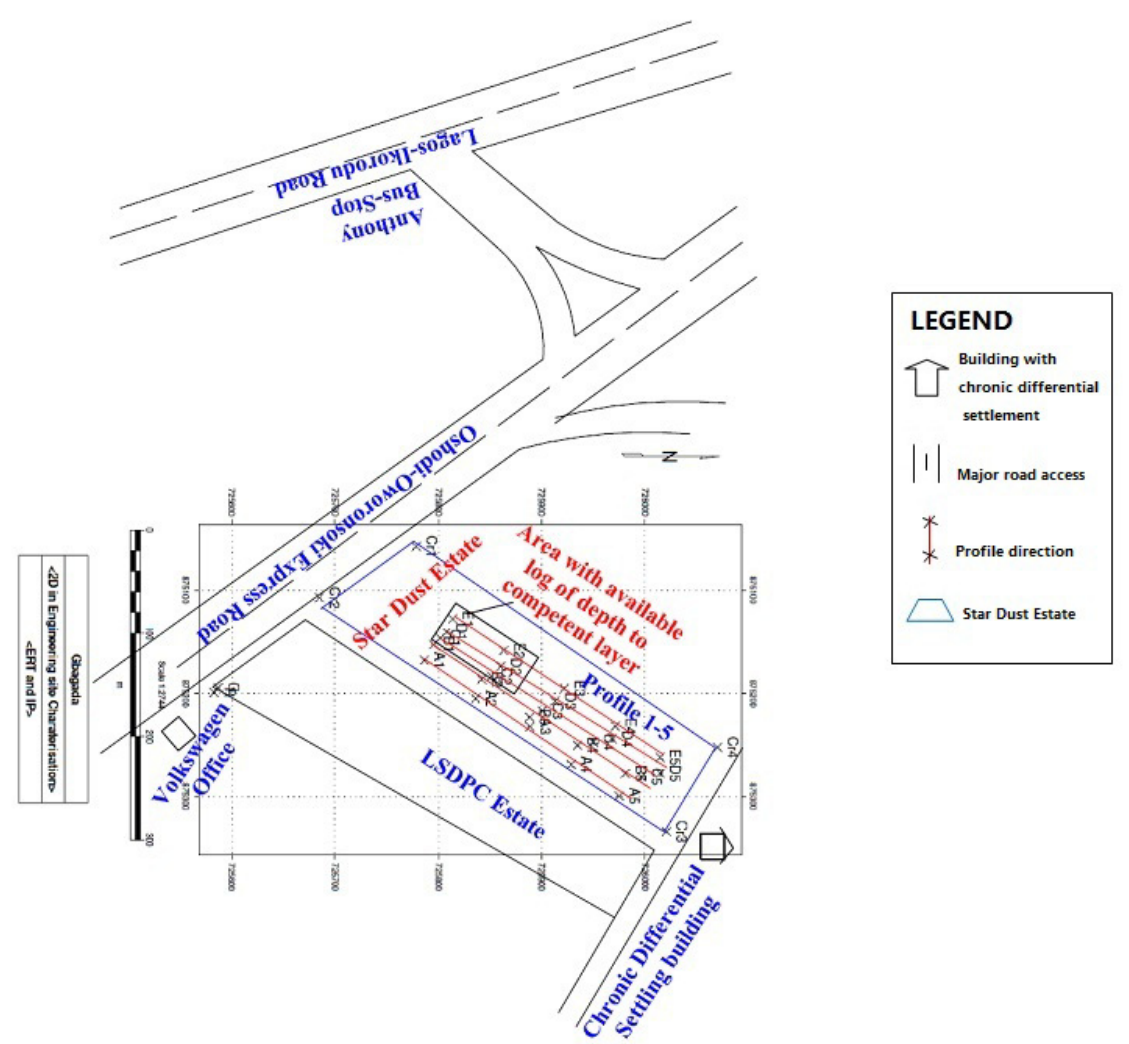

Figure 1. Detailed base map of the survey area showing data acquisition geometry

The geology of the area is derived from regional geology of Lagos made up of the youngest stratigraphic formation in the Dahomey basin named Benin formation also known as the coastal plain sands (Jones \& Hockey, 1964). The lithoral lagoonal deposits are made up of clay, silt, and sands of coastal plains. The coastal belt varies in width from about 8 kilometres near the Republic of Benin border to 24 kilometres towards the eastern end of the Lagos Lagoon (Jones \& Hockey, 1964). It falls within Oligocene to Recent age. 

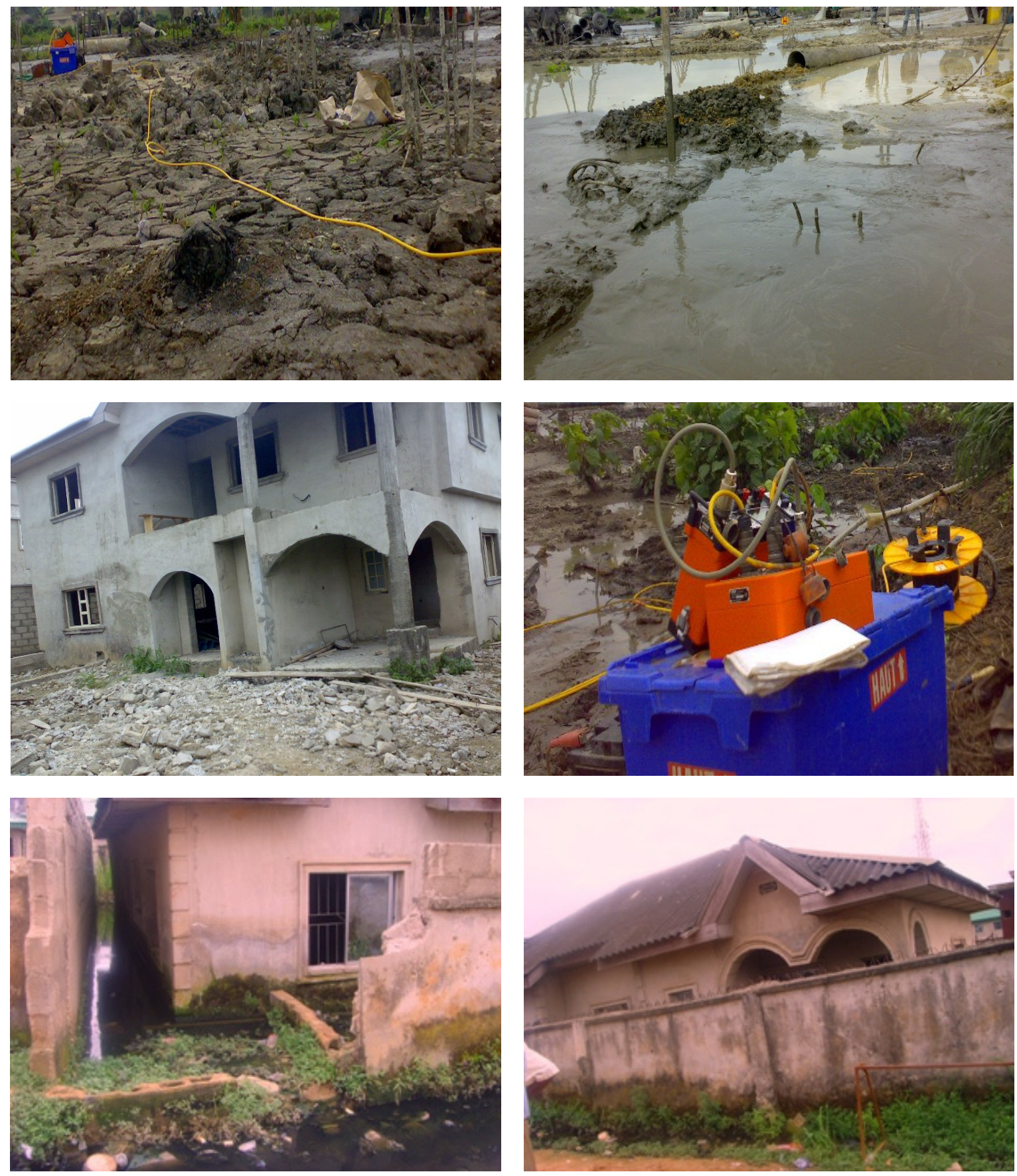

Figure 2. Physical conditions of the site

\section{Methods Adopted}

\subsection{2-D Electrical Resistivity and IP Tomography}

DC Electrical Resistivity Tomography using SAS-1000 Terrameter with 64 electrode system was acquired. The total length of the array is limited by space constrain to $252 \mathrm{~m}$, hence the smallest electrode spacing of $4 \mathrm{~m}$ using gradient electrode configuration was used. IP tomography was acquired alongside the ERT using the same electrode array with the same equipment according to standard practice (Murali \& Patangay, 2006; Ayolabi et al., 2010). In all, a total of five 2-D profiles, parallel to each other at an interval of $10 \mathrm{~m}$, were occupied for both ERT and IPT (Figure 1).

The data acquired was processed using Earth Imager inversion software. This robust-constrained inversion technique was used for each of the 2-D survey data, choosing same resistivity ranges for all the profiles for easy 
interpretation. The Earth Imager program simulated the bulk data into a series of horizontal and vertical rectangular blocks, with each box containing a number of records. The resistivity of each block was calculated to produce an apparent resistivity pseudo-section. The pseudo-section was weighed against the actual measurements for consistency (that is, if the results of the processed pseudo-section varied significantly with the measured data from the percussion drilling values, then we would have assumed our model to be inaccurate, and the model would have been rejected). A measure of the difference was given by the root-mean-square error (AGI, 2003).

\subsection{3-D Electrical Resistivity and IP Tomography}

All geological structures are 3-D in nature, so a fully 3-D resistivity survey using a 3-D interpretation model should in theory give the most accurate results as noted by Loke (2000). However, the possibility of a 3-D resistivity survey is bedeviled by high cost of the survey. Nevertheless, it is known that data acquired in 1-D have been used to study 2-D and 3-D geological structures on a grid of VES (Darlin \& Loke, 1998, Shevnin, Delgado-Rodríguez, Mousatov, Hernández, Martínez, \& Ryjov, 2006). It is equally possible for data acquired in two-dimension to be inverted and interpreted in 3-D; many thanks to the recent development of multi-electrode resistivity surveying instruments (Griffiths, Turnbull, \& Olayinka, 1990) and fast computer inversion software (Loke, 1994) that enables inversion of large volume of data within a reasonable time.

Taken for example Figure 3, it is possible for 2-D ERT acquired over 8 profiles arranged as shown to be inverted in 3-D just as the data could be acquired in 3-D as indicated by Shevnin et al. (2006) soil resistivity cube. Even without profiles 7 and 8 it is still meaningful to invert the resistivity data obtained from the remaining six (6) profiles in 3-D. The third dimension assumes the resistivity variation across all the parallel profiles at the same point. The same Earth Imager software was used to invert both resistivity and IP data for all the profiles in 3-Dimension as confirmed suitable by Ayolabi et al. (2010).

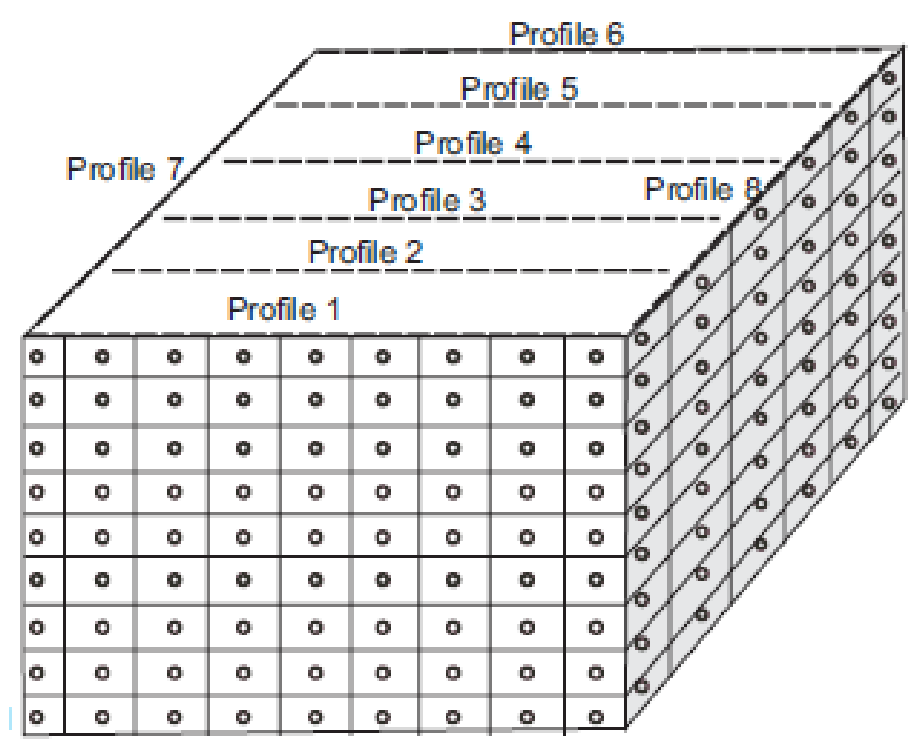

Figure 3. Soil resistivity cube to illustrate how 2-D profiles could be interpreted in 3-D (adapted from Shevnin et al., 2006)

\subsection{Percussion Drilling}

Geophysical inversion suffers from non-uniqueness and one way to reduce this is the use of additional data/information from other sources to constrain geophysical inversion (Sudha, Israil, Mittal, \& Rai, 2009). In order to constrain the accuracy of our ERT survey, three of the ERT profiles were located on percussion drilled holes on the site (Star Dust Estate). The holes were being dug at the time of this field survey; this offers an opportunity of monitoring the logging as the holes were being drilled. It should be noted that the drilled holes covered only one eighth of each of the entire profile length, thus were confined within the first $32 \mathrm{~m}$ of each of the three profiles. 


\section{Results and Discussion}

\subsection{Electrical Resistivity and Induced Polarisation Imaging}

2-D DC Resistivity and IP Imaging derived from resistivity inversion using Earth Imager software were presented as resistivity-depth structures shown in Figures 4a-d. Resistivity distributions of subsurface soil in the area show similar variation of resistivity of subsurface soil at different depths characterized by very low resistivity materials in all the profile lines. The resistivity range lies between 1 to about $1000 \Omega \mathrm{m}$, indicating variation in soil matrix, grain size distribution and water saturation. At near surface (from the depth of about $0.5 \mathrm{~m}$,which is the top soil, to the depth of about $8 \mathrm{~m}$ ) relatively high resistivity values obtained in some of the profiles reveal that of dry sandy clay/clayey sand usually in water saturated condition during wet season but has dried up and lithified during dry season, the period of this survey. These results in multiple cracks expressed at the surface as shown earlier in Figure 2. The decrease in resistivity at a depth below the top soil indicates the presence of saturated soil. This was interpreted as peat/clay with resistivity value below $20 \Omega \mathrm{m}$. Peat material is a highly water-saturated material composed of high percentage of decomposed organic matters, silt and humus soil. Thus, it is capable of sliding the load place over it, making such load mobile. The IP section for this layer ranges from $10-239 \mathrm{mV} / \mathrm{V}$ corroborating the presence of clay/peat materials (Figure 4a-c).

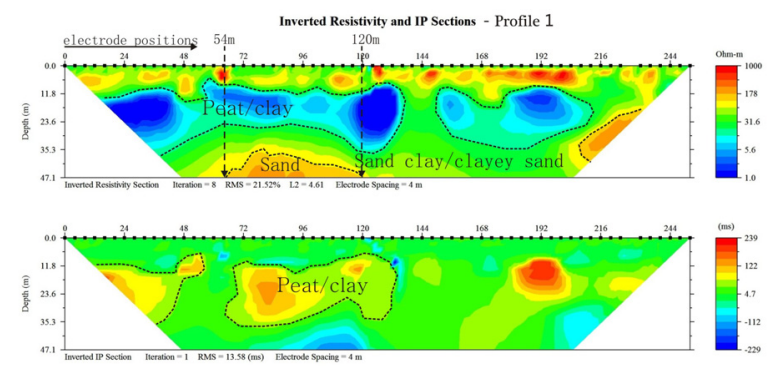

(a)

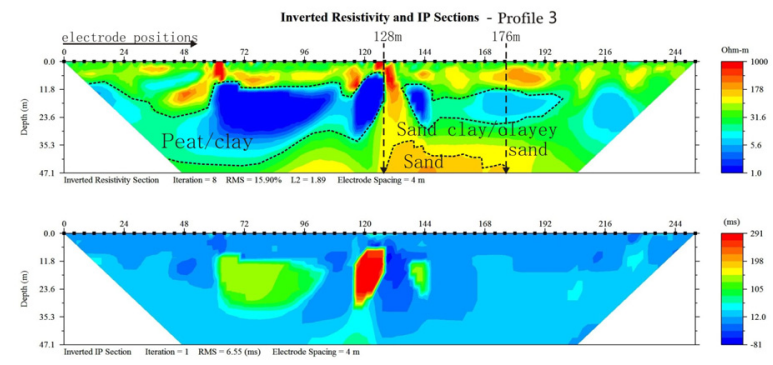

(c)

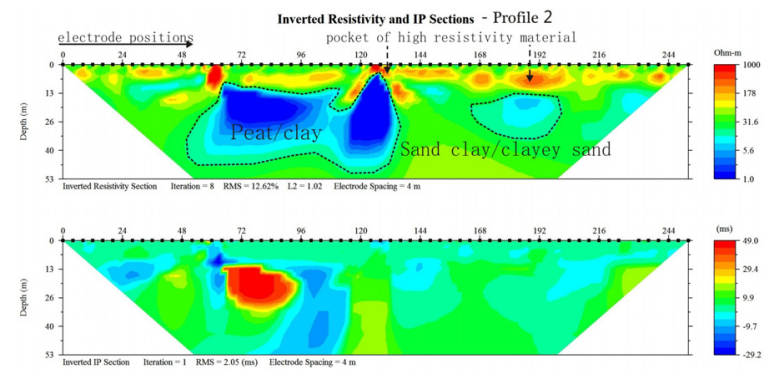

(b)

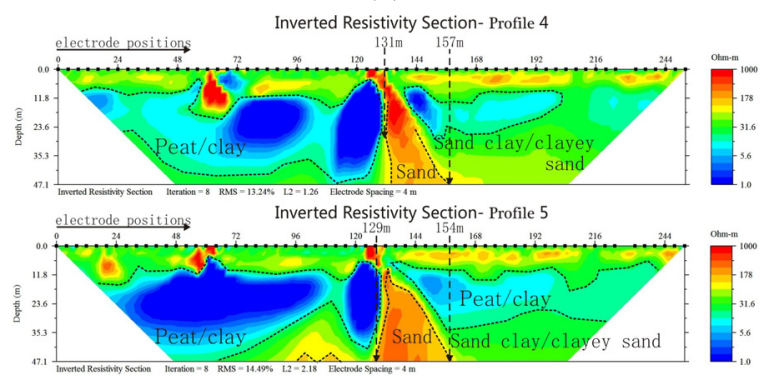

(d)

Figure 4. 2-D resistivity tomography section beneath profiles

The next lithological layer under the peat is sandy clay/clayey sand similar to the near-surface layer. This implies that the peat/clay was sandwich between two clayey sand layers. Hypothetically, we can demonstrate this in the laboratory to find out that when peat are in-between such layer, the layer above tends to be mobile thus creating a dynamic bed under the building structure. Any building construction on such land is bound to fail. This may account for various degrees of failure experienced in the near-by areas (Figure 2).

Lastly, pocket of sandy layers were struck between surface positions 64 and $120 \mathrm{~m}$ on profile 1; positions 128 and $176 \mathrm{~m}$ on profile 3 ; positions 131 and $157 \mathrm{~m}$ on profile 4 ; and positions 129 and $154 \mathrm{~m}$ on profile 5 . These occur at various depths beneath the profiles (at depth range of 10-47 m).

The IP tomography was used to differentiate low resistivity value observed over clayey layer from that of saline/brackish water by the high IP value of the former as seen in Profiles 1, for an example (Figures 4a).

\subsection{3-D Resistivity Tomography Section}

Four of the five profiles were inverted together as a block to generate a single three dimensional image of the subsurface. Resistivity variations parallel, perpendicular and across to the profile lines were presented as resistivity model. 3-D model consists of rectangular cells reaching infinitely in the lateral and horizontal directions both 
perpendiculars to the profiles. The 3-D electrical resistivity tomography in Figure 5 beneath the study area reflects the dominance of clay/peat layer of very low resistivity (2-17 $\Omega \mathrm{m})$ sandwich between layers of highly saturated clayey sand/sandy clay material with resistivity $20-80 \Omega \mathrm{m}$. The overlain and the underlain clayey sand/sandy clay make the mechanically unstable peat/clay layer highly mobile and hence the visible failure/subsidence observed on structures within and around the study area.

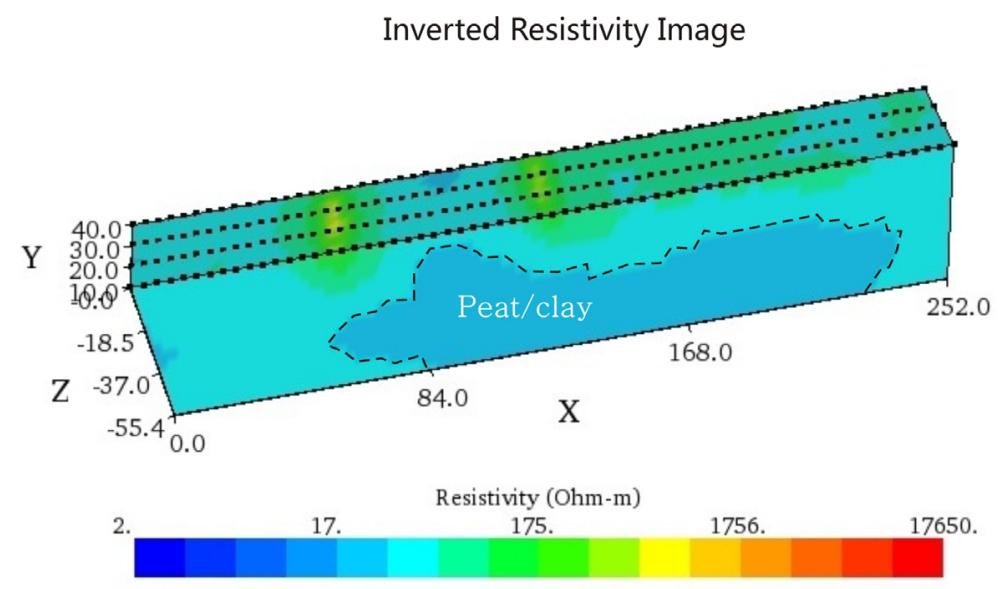

Figure 5. 3-D resistivity tomography beneath the study area

\subsection{Extracted VES along Profiles 2, 3, 4 and 5}

Attempt were made to extract VES data from the 2-D data along profiles 2, 3, 4, and 5 at surface positions $100 \mathrm{~m}$, $110 \mathrm{~m}, 120 \mathrm{~m}, 130 \mathrm{~m}, 140 \mathrm{~m}$, and $150 \mathrm{~m}$ to validate the results of the 2-D and 3-D inversions. The VES curves (Figure 6) were used to prepare the geoelectric sections beneath profiles 2, 3, 4 and 5 (Figure 7). These corroborated the earlier deductions from the 2-D and 3-D resistivity tomography and confirmed the existence of a very thick sequence clay/peat materials sandwich between clayey sand/sandy clay layers.

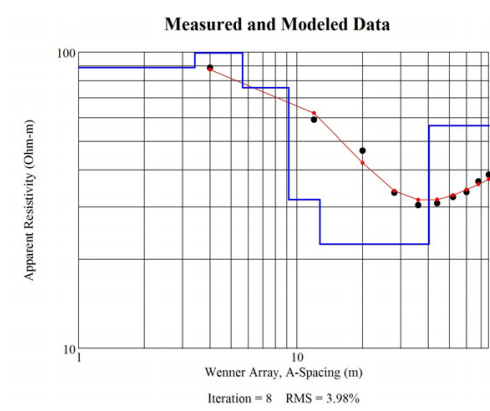

(a)

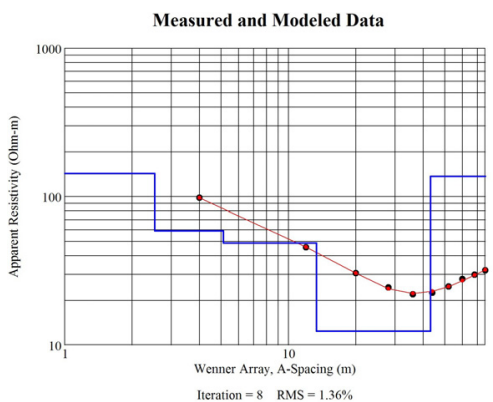

(c)
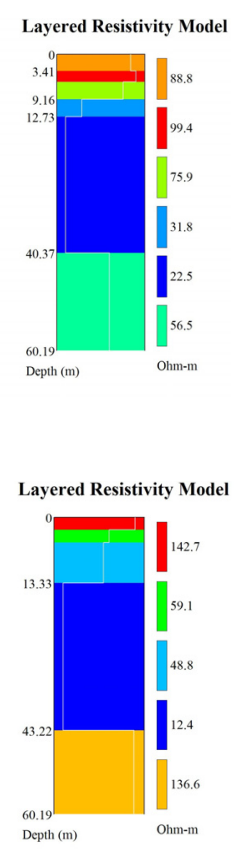

Figure 6. Extracted VES curve at $130 \mathrm{~m}$ along profile 4
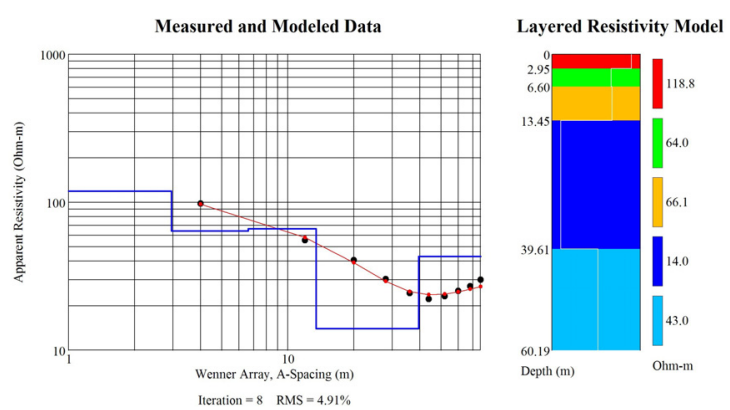

(b)
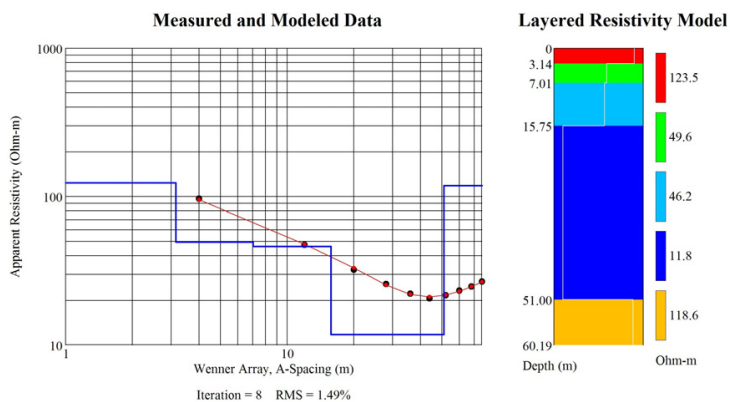

(d) 


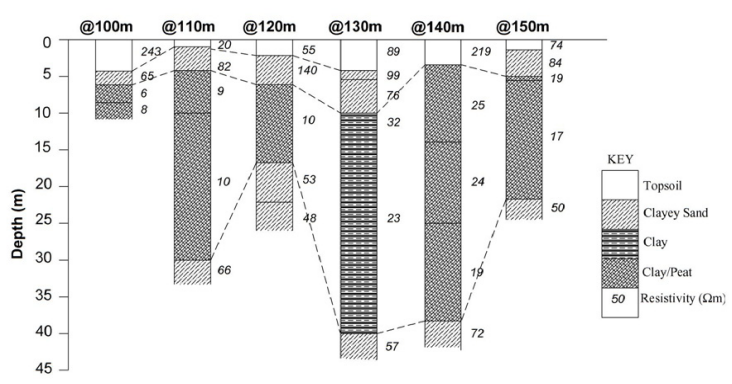

(a)

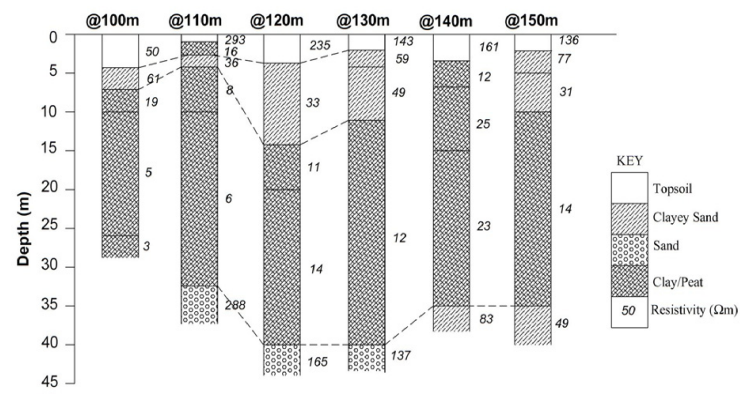

(c)

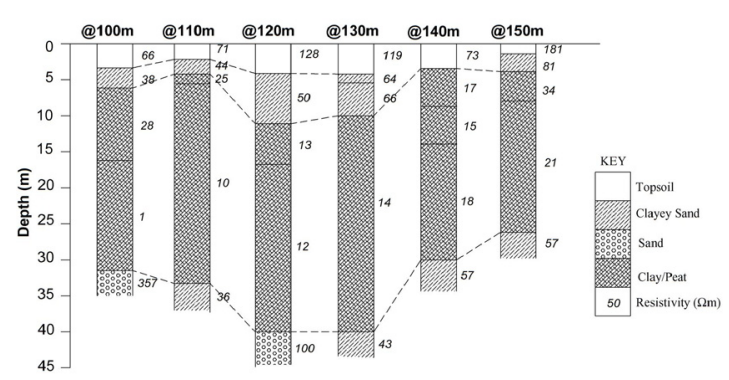

(b)

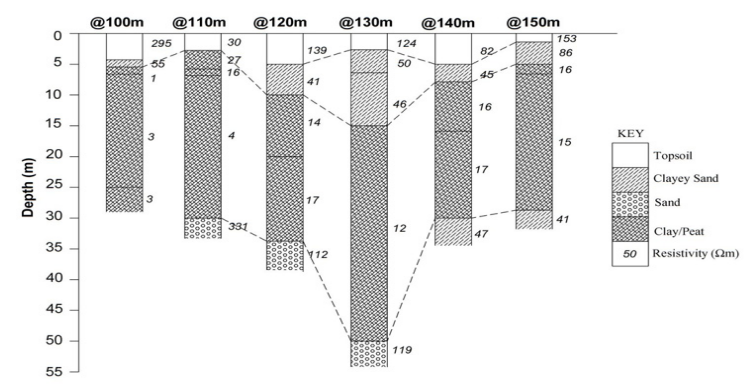

(d)

Figure 7. Geoelectric section along profile 4

\subsection{Percussion Drilling}

Only the depths to competent layer from the percussion drilling were recorded to juxtapose the results of ERT. Various depths recorded vis-a-vis the point on the resistivity profiles are displayed as figures to reflect the sand topography within the estate shown in Figure 8 . This provides the ground truth and confirmed the deductions from various electrical resistivity measurements.
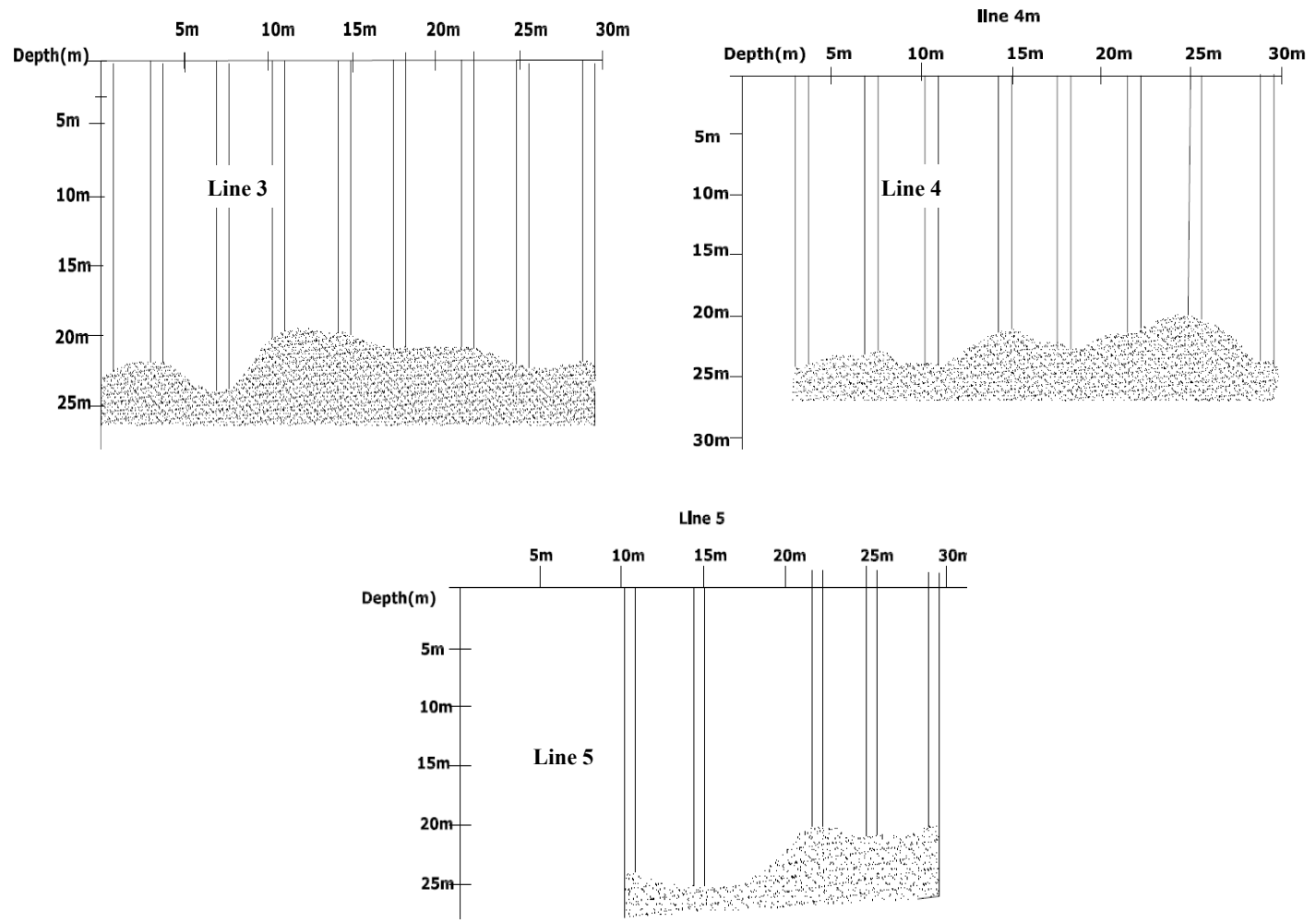

Figure 8. Progression of variation in depths to competent layer based on the percussion drilling 


\subsection{Correlation between the 2-D ERT and Percussion Drilling Data}

The depth to the competent layer along each of the three profiles (Profiles 3, 4 and 5) covered by the percussion drilling was inferred from the 2-D Electrical Resistivity Tomography and percussion drilling exercise. The results presented in Table 1 shows the borehole points on each profile, the nearest electrode position, and depth to competent soil (sand). The depth varies from 20-24 m. For example on Profile 3, depth to competent layer varies from 20-24 $\mathrm{m}$ and 20-45 m for percussion hole and ERT respectively. While on Profiles 4 and 5, the percussion drilled holes and ERT show depth ranges to be between 20-22 $\mathrm{m}$ and 21-24 m; 17-44 $\mathrm{m}$ and 23-47 m respectively. The wide range observed from ERT survey is not unconnected to higher depth of penetration of the method in comparison with depth of penetration of the test holes. Moreso the ERT covers the entire profile in contradistinction to point investigation recorded by percussion drilling.

Table 1. Depth to competent layer attained by the percussion drilling with the profiles proximal to the points drilled

\begin{tabular}{cccccc}
\hline \multirow{2}{*}{$\begin{array}{c}\text { Lateral } \\
\text { distance }(\mathrm{m})\end{array}$} & $\begin{array}{c}\text { Electrode } \\
\text { Number }\end{array}$ & $\begin{array}{c}\text { Position of } \\
\text { Pile }(\mathrm{m})\end{array}$ & $\begin{array}{c}\text { Depth to competent layer attained by percussion drilling and } \\
\text { proximal profiles used }\end{array}$ \\
\cline { 4 - 6 } & & 0 & $\begin{array}{c}\text { Line 3/Profile 3 } \\
\text { Depth }(\mathrm{m})\end{array}$ & $\begin{array}{c}\text { Line 4/Profile 4 } \\
\text { Depth (m) }\end{array}$ & $\begin{array}{c}\text { Line 5/Profile 5 } \\
\text { Depth (m) }\end{array}$ \\
\hline 0 & 0 & 3.3 & 23 & 20 & - \\
4 & 1 & 7.3 & 24 & 20 & 24 \\
8 & 2 & 10.6 & 20 & - & 23 \\
12 & 3 & 14.6 & 20 & 20 & 21 \\
16 & 4 & 17.9 & 21 & 21 & 22.5 \\
20 & 5 & 21.9 & 21 & 20 & 21 \\
24 & 6 & 25.2 & 22 & 22 & 20 \\
28 & 7 & 29.2 & 22 & 20 & 24 \\
32 & 8 & & & 20 & \\
\hline
\end{tabular}

\section{Conclusion}

2-D and 3-D electrical resistivity and induced polarisation tomography were carried out at the proposed Star Dust Residential Estate, Gbagada, Lagos State and the results were analysed using Earth Imaging Inversion software. The results revealed the presence of four geoelectric layers beneath the subsurface, which were identified as top soil, dry and lithified upper sandy/clayey, peat/clay (rich in organic matters and humus material), the lower sandy/clayey soil highly water-saturated and sandy layer confined to the second half of the area. The deeply-seated peat/clay materials $(<20 \Omega \mathrm{m})$ are interspersed with sand, clayey-sand/sandy-clay materials. The DC resistivity result was constrained using percussion drilled holes covering the first few meters on three of the profiles. Depth to competent layer obtained was juxtaposed with depth inferred from ERT, the comparison confirmed variation in depth to competent layer within the estate. This further strengthens the ERT method used for the investigation as a good complement to engineering soil tests for geotechnical site investigation. The depth of penetration of resistivity survey is far more than that of percussion drilling normally carried out during geotechnical investigation. Furthermore a wide lateral coverage was observed for the resistivity tomography as against point observation by geotechnical method. This provides better image of the subsurface and provides room for better engineering design for the foundation of structure in the study area.

\section{References}

AGI. (2003). Earth Imager 2-D resistivity inversion software, version 1.5.10. Advanced Geosciences, Inc., Austin, TX, US.

Akintorinwa, O. J., \& Adesoji, J. I. (2009). Application of geophysical and geotechnical investigations in engineering site evaluation. International Journal of Physical Sciences, 4(8), 443-454.

Anderson, N. L. (2006). Selection of appropriate geophysical techniques generalized protocol based on engineering objectives and site characteristics. Proc., 2006 Highway Geophysics- NDE Conference, 29-47. 
Ayolabi, E. A., Folorunso, A. F., \& Oloruntola, M. O. (2010). Constraining causes of structural failure using electrical resistivity tomography (ERT): A case study of lagos, southwestern, Nigeria. Mineral Wealth, Greece, 156, 7-18.

Ayolabi, E. A., Folorunso, A. F., Adeoti, L., Matthew, S., \& Atakpo, E. (2009). 2-D and 3-D electrical resistivity tomography and its implications. A paper presented at the $4^{\text {th }}$ Annual Research Conference and Fair held at the University of Lagos, Akoka, $8^{\text {th }}$ Jan, 2009. p189.

Dahlin, T., \& Loke, M. H. (1998). Resolution of 2D Wenner resistivity imaging as assessed by numerical modeling. Journal of Applied Geophysics, 38, 237-249. http://dx.doi.org/10.1016/S0926-9851(97)00030-X

Elawadi, E., El-Qady, G., Nigm, A., Shaaban, F., \& Ushijima, K. (2006). Integrated geophysical survey for site investigation at a new dwelling area, egypt. Jour. Env. \& Engg. Geophy, 11(4), $249-259$. http://dx.doi.org/10.2113/JEEG11.4.249

Folorunso, A. F., Ayolabi, E. A., Ariyo, S. O., \& Oyebanjo, I. O. (2012). Fault presence under a failing building complex mapped by electrical resistivity tomography. Mineral Wealth, Greece (accepted, in press)

Griffiths, D. H., Turnbull, J., \& Olayinka, A. I. (1990). Two-dimensional resistivity mapping with a computercontrolled array. First Break, 8, 121-129.

Jones, H. A., \& Hockey, R. D. (1964). The geology of part of southwestern Nigeria. Geological Survey of Nig. Bull, 31,101 .

Loke, M. H. (1994). The inversion of two-dimensional resistivity data. Unpubl. PhD thesis, Unversity of Birmingham.

Loke, M. H. (2000). Electrical imaging surveys for environmental and engineering studies: a practical guide to 2D and 3D surveys. P. 59.

Murali, S., \& Patangay, N. S. (2006). Principles of application of groundwater Geophysics. Association of Geophysicists, Hyderabad, India, (3rd ed.). p. 371.

Owunu-Nimo, F., \& Boadu, F. K. (2010). Influence of petrophysical and geotechnical engineering properties on the electrical response of unconsolidated earth materials. Geophysics, 75(3), 21-29. http://dx.doi.org/10.1190/1.3374465

Reynolds, J. M. (1997). An introduction to applied and environmental geophysics, West Sussex, England: John Wiley \& Sons Ltd., pp. 796.

Roth, M. S. J., Nyquist, J. E., \& Guzas, B. (2000). Locating subsurface voids in karst: A comparison of multielectrode earth resistivity testing and gravity testing: Proceedings of SAGEEP 2000, 359-365.

Schoor, M. V. (2002). Detection of sinkholes using 2D electric resistivity imaging. Journal of Applied Geophysics, 50, 393-399. http://dx.doi.org/10.1016/S0926-9851(02)00166-0

Shevnin, V., Delgado-Rodríguez, O., Mousatov, A, Hernández, D. F., Martínez, H. Z., \& Ryjov, A. (2006). Estimation of Soil Petrophysical parameters from Resistivity Data: application to Oil-Contaminated Site Characterization. Geofisica Internacional, 45(3), 179-193.

Sirles, P. C. (2006). Use of Geophysics for Transportation Projects. Transportation Research Board of the National Academies, Washington, D. C. Project 20-5, Topic 36-08.

Sudha, K., Israil, M., Mittal, S., \& Rai, J. (2009). Soil characterization using electrical resistivity tomography and geotechnical investigations. Journal of Applied Geophysics, Elsevier, 67, 74-79. http://dx.doi.org/10.1016/j.jappgeo.2008.09.012

Wightman, W. E., Jalinoos, F., Sirles, P., \& Hanna, K. (2004). Application of geophysical methods to highway-related problems. Publication No. FHWA-IF-04-021. Central Federal Lands Highway Division, FHWA, U. S. Department of Transportation. pp. 57-69. 